\title{
Changes in leukocyte gene expression profiles induced by antineoplastic chemotherapy
}

\author{
REBECA GONZÁLEZ-FERNÁNDEZ ${ }^{1}$, MANUEL MORALES ${ }^{2,3}$, JULIO AVILA ${ }^{1}$ and PABLO MARTÍN-VASALLO ${ }^{1}$ \\ ${ }^{1}$ Laboratory of Developmental Biology, Department of Biochemistry and Molecular Biology, University of La Laguna, \\ La Laguna 38201; ${ }^{2}$ Service of Medical Oncology, Hospital Universitario Ntra Sra de Candelaria, \\ Santa Cruz de Tenerife 38010; ${ }^{3}$ Medical Oncology, Hospiten Rambla, Santa Cruz de Tenerife 38001, Tenerife, Spain
}

Received January 17, 2012; Accepted March 28, 2012

DOI: $10.3892 /$ ol.2012.669

\begin{abstract}
In the present study, we studied changes in gene expression induced by chemotherapy (CT) on normal peripheral blood leukocytes (PBLs), at baseline and following three CT cycles, in order to identify which genes were specifically affected and were potentially useful as biomarkers for a personalised prognosis and follow-up. A PBL subtraction cDNA library was constructed from four patients undergoing CT with paclitaxel and carboplatin (PC). mRNA from the PBLs was isolated prior to the patients receiving the first cycle and following the completion of the third cycle. The library was screened and the expression of the identified genes was studied in PBLs obtained from patients suffering from cancer prior to and following three cycles of PC and a reference group of patients undergoing treatment with Adriamycincyclophosphamide (AC). From the 1,200 screened colonies, 65 positive clones showed varied expression intensity and were sequenced; 27 of these were mitochondrial DNA and 38 clones (27 different) were coded for cytosolic and nuclear proteins. The genes that were studied in patients undergoing CT were ATM (ataxia-telangiectasia mutated gene), eIF4B (translation initiation factor 4B), MATR3 (Matrin 3), MORC3 (microrchidia 3), PCMTD2 (protein-Lisoaspartate O-methyltransferase), PDCD10 (programmed cell death gene 10), PSMB1 (proteasome subunit type $\beta$ ), RMND5A (required for meiotic nuclear division 5 homologue A), RUNX2 (runt-related transcription factor 2), SACM1L (suppressor of actin mutations 1-like), TMEM66 (transmembrane protein 66) and ZNF644 (zinc finger protein 644). Certain variations were observed in the expression of the genes that are involved in drug resistance mechanisms,
\end{abstract}

Correspondence to: Dr Pablo Martín-Vasallo, Laboratory of Developmental Biology, Department of Biochemistry and Molecular Biology, University of La Laguna, Av. Astrofísico Sánchez s/n, La Laguna 38201, Tenerife, Spain

E-mail:pmartin@ull.es

Key words: leukocyte, gene expression, chemotherapy, paclitaxel, carboplatin some of which may be secondary to non-desirable effects and others of which may cause the undesired effects of CT. The expression of genes with a dynamic cellular role showed a marked positive correlation, indicating that their upregulation may be involved in a specific pattern of cell survival versus apoptosis in response to the cell damage induced by CT. Whether these CT-induced changes are random or directed in a specific selection-evolution manner needs to be elucidated.

\section{Introduction}

Anticancer chemotherapy (CT) functions by producing metabolic alterations, changing the structure and function of DNA, affecting mitotic microtubules or triggering apoptotic pathways in the target cells. As well as beneficial effects in cancer cells, $\mathrm{CT}$ results in non-desirable cytotoxic effects in normal healthy tissues. Bone marrow is most susceptible to the non-specific effects of CT; damage may result in short-term toxicity, such as myelosuppression and anaemia, or in long-term problems such as myelodysplastic syndromes or secondary leukaemia forms.

To investigate the changes in gene expression and the possible pathways involved in CT-induced cytotoxicity in normal blood cells, we studied peripheral blood leukocytes (PBLs) prior to and following three cycles of CT.

Most cytotoxic anticancer drugs target DNA directly through reactive metabolites or indirectly through incorporation into DNA (nucleotide analogues) or the blockade of DNA-metabolising enzymes, including polymerases and topoisomerases $(1,2)$. This DNA damage triggers signalling pathways that ultimately lead to cell death $(1,2)$.

Paclitaxel is a tubulin-binding agent that stabilises microtubules ( $\alpha$ - $\beta$-tubulin heterodimers) in the microtubule-GDP complex, thereby inhibiting the dynamic role of the complex and consequently arresting mitosis $(1,2)$. Platinum chemotherapeutic agents, including carboplatin, halt the cell cycle by forming stable complexes with DNA. The efficacy of chemotherapeutic agents in most types of cancer is limited by the development of resistance. Resistance to paclitaxel suggests the aberrant expression of $\beta$-tubulin isotypes, usually $\beta$ III-tubulin, or microtubule-regulating proteins (3). Resistance to platinum is commonly developed by the DNA nucleotide excision repair pathways as repair or mismatch repair, such as excision repair cross-complementation group 1 enzyme (ERCC1) (4). 
Doxorubicin interacts with DNA by intercalating between two base pairs, blocking the progression of topoisomerase II and thereby preventing the process of replication (2). Resistance to doxorubicin is multifactorial, including increased levels of factors involved in reducing the intracellular drug concentration by increasing drug extrusion through membrane-associated pumps, the altered expression of topoisomerase II, increased ability of the cell to repair DNA damage and changes in gene expression that reduce the apoptotic response $(5,6)$.

Cyclophosphamide mainly acts through its metabolite, phosphoramide mustard, which is an irreversible interstrand DNA crosslinker that causes cell death. Cytochrome P450 (CYP), glutathione S-transferase (GST) and ALDH protect the cells in tissues with rapid cell turnover against the toxic effects of phosphoramide mustard (7) by converting aldophosphamide to molecules that do not produce the toxic metabolites.

The aim of this study was to identify a group of genes in PBLs whose expression is modified by CT.

\section{Materials and methods}

Patients. This study was approved by the Ethics Committee of La Laguna University and HUNSC and all the subjects signed informed consent documents prior to entering the study. The study subjects were Caucasian, of European origin and recruited from the reference medical area of the hospital. The patients in this study were administered CT only (not radiotherapy or any other adjuvant therapy), and this was their first CT. Two groups were analysed: patients undergoing carboplatin-paclitaxel (PC) treatment and, as a reference, patients treated with doxorubicin (Adriamycin)-cyclophosphamide (AC).

Leukocyte isolation. PBLs were obtained immediately prior to patients undergoing the first cycle and following the third cycle (at the time the 4th cycle was administered). A volume of $1 \mathrm{X}$ PBS (1.9 mM NaH $\mathrm{PO}_{4}, 8.1 \mathrm{mM} \mathrm{Na} \mathrm{HPO}_{4}, 154 \mathrm{mM} \mathrm{NaCl}$ ) was added to an identical volume of freshly collected blood and mixed gently. The mix was placed over $5 \mathrm{ml}$ Ficoll-Hypaque $(\mathrm{d}=1.077 \mathrm{~g} / \mathrm{ml})$ (Sigma, St. Louis, MO, USA) and centrifuged for $30 \mathrm{~min}$ at $600 \mathrm{x}$ g. The intermediate layer (mononuclear white cells) was aspirated and washed three times in three volumes of HBSS (5.4 mM KCl, $0.3 \mathrm{mM} \mathrm{Na}_{2} \mathrm{HPO}_{4}, 0.4 \mathrm{mM} \mathrm{KH}_{2} \mathrm{PO}_{4}$, $4.2 \mathrm{mM} \mathrm{NaHCO}_{3}, 1.3 \mathrm{mM} \mathrm{CaCl}_{2}, 0.5 \mathrm{mM} \mathrm{MgCl}, 0.6 \mathrm{mM}$ $\mathrm{MgSO}_{4}, 137 \mathrm{mM} \mathrm{NaCl}, 5.6 \mathrm{mM}$ D-glucose, $0.02 \%$ phenol red) and centrifuged at $300 \mathrm{x} \mathrm{g}$ for $10 \mathrm{~min}$. The pellet containing the cells was resuspended in $1 \mathrm{ml}$ of PBS. The trypan blue test and cell counting in a Neubauer chamber were performed. The amount of collected cells ranged from 3 to $4 \times 10^{6}$ cells.

PBL mRNA extraction, double stranded (ds) cDNA synthesis and PCR amplification. The collected PBLs from $5 \mathrm{ml}$ of blood were spun at $300 \mathrm{x}$ g for $5 \mathrm{~min}$ and $\mathrm{mRNA}$ was obtained from the cell pellet using the Total SV RNA Isolation system (Promega Corporation, Madison, WI, USA), according to the manufacturer's instructions. cDNA was synthesised using the iScript cDNA Synthesis kit (Bio-Rad, Mannheim, Germany) for the real-time quantitative RT-PCR (qRT-PCR) assay and the Super SMART PCR cDNA Synthesis kit (Clontech Laboratories, Mountain View, CA, USA) for the subtraction library according to the manufacturer's instructions. $d s-c D N A$ subtraction and library construction. The subtraction library was constructed using the PCR Select cDNA Subtraction kit (Clontech Laboratories) according to the manufacturer's instructions, with ds-cDNA pools obtained from the white cells of the four patients immediately prior to undergoing the first cycle and at the time the 4th cycle of PC was administered, using equal amounts of cDNA from each patient. The pool of differentially expressed cDNA was cloned into the $\mathrm{pBSK}^{+}$vector in competent $E$. coli, XL-2-Blue cells.

Dot-blot screening. Probes were used to subtract the cDNA from the PBLs obtained pre- and post-treatment and were digoxigenin-dUTP labeled using the DIG DNA labeling kit (Roche Diagnostics, Mannheim, Germany). Colonies from the library were seeded in plates containing LB-ampicillin $(0.1 \mathrm{mg} /$ $\mathrm{ml}), \mathrm{X}-\mathrm{Gal}(40 \mu \mathrm{g} / \mathrm{ml})$ and IPTG $(0.2 \mathrm{mM})$ solid medium and incubated at $37^{\circ} \mathrm{C}$ overnight. The colonies were selected and placed into 96 -well plates in liquid LB-ampicillin $(0.1 \mathrm{mg} / \mathrm{m})$ medium and incubated at $37^{\circ} \mathrm{C}$ overnight. A volume of $1 \mu 1$ from each cultured well was placed in duplicate onto two nylon membranes (Roche Diagnostics) and incubated at $37^{\circ} \mathrm{C}$ overnight over LB-ampicillin $(0.1 \mathrm{mg} / \mathrm{ml})$ solid medium plates. Duplicate membranes were probed with both probes (8) and positive clones were re-checked by double-dot-blotting of the PCR amplified product using T3 and T7 flanking sequence primers (8).

DNA sequencing and sequence identification. DNA sequencing was performed at La Laguna University Sequencing Facility. DNA for sequencing was prepared using the Qiaprep kit (Qiagen, Hilden, Germany) according to the manufacturer's instructions. Sequence alignments of the sequences with those in the GenBank, EMBL, DDBJ and PDB databases were performed using the BLASTN and BLASTX algorithms (9).

$q R T-P C R$. mRNA was extracted from the PBLs to perform qRT-PCR for the selected genes (Table I) and the corresponding cDNAs were synthesised as described above. PCR assays were carried out using the Bio-Rad CFX96 Real-Time PCR system (Hercules, CA, USA). The specific primers for each gene are shown in Table I. PCR was performed using the SYBR-Green Supermix (Bio-Rad). The amplification reactions were performed in a $10-\mu 1$ final volume containing 2X SYBR-Green Supermix and $10 \mu \mathrm{M}$ of each primer. Each sample was analysed in triplicate and multiple water blanks were included. $\beta$-actin was amplified as a reference for mRNA quantification. The relative gene expression was presented as arbitrary units of the ratio of $\mathrm{Ct}_{\text {gene }} / \mathrm{Ct}_{\beta \text {-actin }}$.

Statistical analysis. Statistical analysis was performed using the SPSS software and Pearson's correlation coefficient. $\mathrm{P}<0.01$ was considered statistically significant. The KolmogorovSmirnov analysis of these data showed that the expression values of these genes did not have a normal Gaussian distribution. Thus, in order to use the Pearson's correlation coefficient, we obtained the decimal logarithm of each expression value. A Kolmogorov-Smirnov test of the logarithm values showed a normal distribution. 
Table I. Primers and annealing temperatures used for qRT-PCR of selected genes.

\begin{tabular}{|c|c|c|c|}
\hline Gene & Primer & Sequence $\left(5^{\prime} \rightarrow 3^{\prime}\right)$ & $\operatorname{Tm}\left({ }^{\circ} \mathrm{C}\right)$ \\
\hline \multirow[t]{2}{*}{ ATM } & ATM-F & AACGAGCCGATCCACAACC & 63.4 \\
\hline & ATM-R & CTCATGTAGTCCACAACAGCAAGC & 63.3 \\
\hline \multirow[t]{2}{*}{ eIF4B } & eIF4B-F & GGCAAAAAGGATCAAGACTCC & 60.1 \\
\hline & eIF4B-R & CCATCAACAGAGAGAGCAGC & 58.7 \\
\hline \multirow[t]{2}{*}{ MATR3 } & MATR3-F & CCTAGTCTCAACCCAGTGC & 55.7 \\
\hline & MATR3-R & CATCССТАСАССТТТСТСС & 54.5 \\
\hline \multirow[t]{2}{*}{ MORC3 } & MORC3-F & TCCACCTCAGTCTGAACC & 54.1 \\
\hline & MORC3-R & TCAAACTGACTACTCAATCTCC & 53.7 \\
\hline \multirow[t]{2}{*}{ PCMTD2 } & PCMTD2-F & ATGCAAAGCAGAAACTGG & 54.8 \\
\hline & PCMTD2-R & CGATCATACTGAGAACAATCC & 54.7 \\
\hline \multirow[t]{2}{*}{ PDCD10 } & PDCD10-F & CGATCATACTGAGAACAATCC & 50.2 \\
\hline & PDCD10-R & ATACGAAGAAGGGACTCC & 51.4 \\
\hline \multirow[t]{2}{*}{ PSMB1 } & PSMB1-F & AGACTTGGGGATGGAACC & 57.2 \\
\hline & PSMB1-R & TCACTCAATCGAGTATCAGAAGC & 58.6 \\
\hline \multirow[t]{2}{*}{ RMND5A } & RMND5A-F & AGACCCAAGTCAGAAGGAACC & 59.6 \\
\hline & RMND5A-R & GGAGCTGTTTTGAGCTATAAGC & 57.5 \\
\hline \multirow[t]{2}{*}{ RUNX2 } & RUNX2-F & GCCTCTGCTGTTATGAAAAACC & 60.1 \\
\hline & RUNX2-R & ATGGTCAAGGTGAAACTCTTGC & 60.5 \\
\hline \multirow[t]{2}{*}{ SACM1L } & SACM1L-F & GATTTGACCCATACTTTGC & 53 \\
\hline & SACM1L-R & TGACCATTCCATACAAACC & 54 \\
\hline \multirow[t]{2}{*}{ TMEM66 } & TMEM66-F & TATCСТCСАТТTТСССАСС & 57.2 \\
\hline & TMEM66-R & CAAAACCAGAAGTTGCACC & 56.7 \\
\hline \multirow[t]{2}{*}{ ZNF644 } & ZNF644-F & GGACTTGACTATGCACTCAGC & 57.6 \\
\hline & ZNF644-R & TGTAAACCTCGTCAGCACC & 57.2 \\
\hline \multirow[t]{2}{*}{$\beta$-actin } & ACT-F & СTTCСTTCCTGGGCATGG & 61.6 \\
\hline & ACT-R & GCCGCCAGACAGCACTGT & 63.7 \\
\hline
\end{tabular}

qRT-PCR, real-time quantitative RT-PCR; Tm, annealing temperature; ATM, ataxia-telangiectasia mutated gene; eIF4B, translation initiation factor 4B; MATR3, Matrin 3; MORC3, microrchidia 3; PCMTD2, protein-L-isoaspartate O-methyltransferase; PDCD10, programmed cell death gene 10; PSMB1, proteasome subunit type $\beta$; RMND5A, required for meiotic nuclear division 5 homologue A; RUNX2, runt-related transcription factor 2; SACM1L, suppressor of actin mutations 1-like; TMEM66, transmembrane protein 66; ZNF644, zinc finger protein 644; ACT, actin; F, forward; R, reverse.

\section{Results}

Construction and screening of the subtracted cDNA library. We constructed a cDNA subtraction library from the PBLs obtained from patients immediately prior to undergoing the first cycle of CT and at the time the 4th cycle was administered (after completing 3 cycles). Screening of 1,200 colonies yielded a total of 65 positive clones of variable expression intensity. The sequencing and identification of the clones following CT treatment revealed that 27 were mitochondrial DNA and 38 (38 clones but 27 different genes) were coded for cytosolic and nuclear proteins (Tables II and III).

We classified the identified genes into seven groups according to the function of the protein they encode: protein synthesis activators (either at the transcriptional or translational level), DNA repair mechanisms, signal transduction pathways (apoptosis-survival), protein repair enzymes, cellular multidynamic systems, integral parts of metabolic pathways and unknown function (Table II).
Genes and proteins analysed in cancer patients undergoing $C T$. Certain genes were selected for the specific study of variations in their expression levels in two series of patients undergoing CT (Table II). The selected genes were ATM (ataxia-telangiectasia mutated gene), eIF4B (translation initiation factor 4B), MATR3 (Matrin 3), MORC3 (microrchidia 3), PCMTD2 (protein-L-isoaspartate O-methyltransferase), PDCD10 (programmed cell death gene 10), PSMB1 (proteasome subunit type $\beta$ ), RMND5A (required for meiotic nuclear division 5 homologue A), RUNX2 (runt-related transcription factor 2), SACM1L (suppressor of actin mutations 1-like), TMEM66 (transmembrane protein 66) and ZNF644 (zinc finger protein 644). To assess the specificity of carboplatin and paclitaxel on the regulatory response, a group of patients undergoing treatment with doxorubicin (Adriamycin) and cyclophosphamide was analysed concomitantly. Quantitation of the gene expression was carried out using qRT-PCR relative to actin. 
Table II. Identified genes coding for cytosolic and nuclear proteins whose expression levels varied following treatment with paclitaxel and carboplatin chemotherapy. ${ }^{\text {a }}$

\begin{tabular}{|c|c|c|}
\hline Identified gene & Clones & Diff signal int \\
\hline \multicolumn{3}{|l|}{ Transcription and translation factors } \\
\hline eIF4B & 1 & Medium \\
\hline H2AFZ & 1 & Low \\
\hline RUNX2 & 1 & High \\
\hline ZNF644 & 1 & Medium \\
\hline \multicolumn{3}{|l|}{ DNA repair } \\
\hline ATM & 2 & Medium \\
\hline \multicolumn{3}{|l|}{ Signal transduction } \\
\hline MORC3 & 7 & High \\
\hline PDCD10 & 1 & High \\
\hline \multicolumn{3}{|l|}{ Protein remodelling } \\
\hline PCMTD2 & 1 & Low \\
\hline PSMB1 & 3 & High \\
\hline \multicolumn{3}{|l|}{ Cellular multidynamic systems } \\
\hline ADD3 & 1 & Low \\
\hline MATR3 & 1 & Low \\
\hline RMND5A & 1 & Medium \\
\hline SACM1L & 1 & Low \\
\hline \multicolumn{3}{|l|}{ Metabolic pathways } \\
\hline COQ3 & 1 & High \\
\hline CSNK1A1 & 1 & High \\
\hline FAR1 & 1 & Low \\
\hline FTL & 1 & High \\
\hline GMDS & 1 & Medium \\
\hline SORL1 & 1 & Medium \\
\hline \multicolumn{3}{|l|}{ Unknown } \\
\hline ANKRD10 & 1 & Medium \\
\hline Chromosome 8 clone RP11-320N21 & 1 & High \\
\hline Chromosome 1 clone RP11-545E24 & 2 & Low \\
\hline Chromosome 5 clone RP11-1C1 & 2 & Low \\
\hline Clone DNA16445 SELT (UNQ150) & 1 & High \\
\hline F8A1 & 1 & Medium \\
\hline TMEM66 & 1 & Low \\
\hline TMEM209 & 1 & Low \\
\hline
\end{tabular}

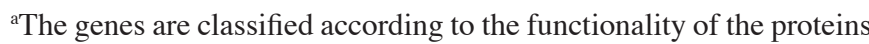
they encode. Diff signal int, different signal intensity; eIF4B, translation initiation factor 4B; H2AFZ, H2A histone family member Z; RUNX2, runt-related transcription factor 2; ZNF644, zinc finger protein 644; ATM, ataxia-telangiectasia mutated gene; MORC3, microrchidia 3; PDCD10, programmed cell death gene 10; PCMTD2, protein-L-isoaspartate O-methyltransferase; PSMB1, proteasome subunit type $\beta$; ADD3, adducin 3; MATR3, Matrin 3; RMND5A, required for meiotic nuclear division 5 homologue A; SACM1L, suppressor of actin mutations 1-like; COQ3, coenzyme Q3 homologue; CSNK1A1, casein kinase 1, alpha 1; FAR1, fatty acyl CoA reductase 1; FTL, ferritin, light polypeptide; GMDS, GDP-mannose 4,6-dehydratase; SORL1, sortilin-related receptor, L; ANKRD10, ankyrin repeat domain 10; RP11, retinitis pigmentosa; F8A1, coagulation factor VIII-associated 1; TMEM, transmembrane protein.
Table III. Identified leukocyte mitochondrial genes whose expression levels varied following paclitaxel and carboplatin chemotherapy.

Identified gene

Clones Diff signal int

16S ribosomal RNA gene

Isolate TV15 mitochondrion

Haplogroup J1b2 mitochondrion

Haplogroup U5b1 mitochondrion

Haplogroup U5b2 mitochondrion

Haplogroup K2a mitochondrion

$\begin{array}{ll}3 & \text { High } \\ 1 & \text { Medium } \\ 4 & \text { Medium } \\ 2 & \text { High } \\ 1 & \text { High } \\ 2 & \text { Medium }\end{array}$

ATP synthase, $\mathrm{H}^{+}$transporting, mitochondrial F1 complex, O subunit 1 Medium Haplogroup H6* mitochondrion 2 High Isolate L332 mitochondrion $\quad 1 \quad$ High Haplogroup H2a1 mitochondrion $\quad 1 \quad$ High Isolate MTDNA381 mitochondrion 1 High Isolate ST024 mitochondrion $\quad 1 \quad$ Medium Haplotype U4a mitochondrion $\quad 1 \quad$ High Isolate Koryak 28 mitochondrion $\quad 1 \quad$ High Isolate MTDNA538 mitochondrion 1 Medium Haplotype H5 mitochondrion $\quad 3 \quad$ High Isolate Tub28 mitochondrion $\quad 1 \quad$ Medium

Diff signal int, different signal intensity.

Analysis of variation in the expression of selected genes induced by $C T$. The relative gene expression prior to and following CT with PC (Table IVA) or AC (Table IVB) was evaluated. In almost all of the genes studied there was a significant variation of expression, with up- and downregulation in patients treated with PC and AC. Only a few cases (one or two per group) of certain genes (Tables IVA and B) did not show significant variation in their expression levels. Column ' $\mathrm{N}$ ' in Tables IVA and B indicates the number of cases in which the expression of each gene was increased or decreased significantly and the column 'Ratio' shows the mean of the increased or decreased ratio between the relative gene expression prior to and following CT (Pre-/Post-CT) for each patient. Genes with the greatest increases in expression induced by $\mathrm{PC}$ were RMND5A (7-fold), PDCD10 (3.9-fold) and MATR3 (4.5-fold). The increases in gene expression induced by AC therapy ranged between 1.4- and 2.1-fold. Decrease of the expression of the studied genes was shown in fewer cases at levels that range about a half of the previous expression to $\mathrm{CT}$.

Results of the analysis of correlation among the genes with up- or downregulated expression are shown in Fig. 1.

\section{Discussion}

Areas of progress in the fields of cancer biology and CT currently include strategies for identifying genes that are differentially expressed in different situations, including normal and cancer cells or, as in this study, prior to and following CT. Several methods have been used for these analyses, including SAGE (serial analysis of gene expression) (10), the differential display 
Table IV. Mean and typical error of relative gene expression, prior to and following chemotherapy.

A, Relative gene expression prior to and following chemotherapy with paclitaxel and carboplatin

\begin{tabular}{|c|c|c|c|c|c|}
\hline Gene & Expression & $\mathrm{N}$ & Pre-CT & Post-CT & Ratio \\
\hline ATM & $\begin{array}{l}\text { Increase } \\
\text { Decrease } \\
\text { No change }\end{array}$ & $\begin{array}{l}6 \\
2 \\
0\end{array}$ & $\begin{array}{r}866 \pm 371 \\
2479 \pm 839\end{array}$ & $\begin{array}{l}2301 \pm 1000 \\
1316 \pm 303\end{array}$ & $\begin{array}{l}2.8 \pm 0.20 \\
0.6 \pm 0.05\end{array}$ \\
\hline eIF4B & $\begin{array}{l}\text { Increase } \\
\text { Decrease } \\
\text { No change }\end{array}$ & $\begin{array}{l}3 \\
5 \\
0\end{array}$ & $\begin{array}{l}11730 \pm 3958 \\
14588 \pm 6386\end{array}$ & $\begin{array}{r}20092 \pm 6688 \\
5358 \pm 1578\end{array}$ & $\begin{array}{l}1.8 \pm 0.18 \\
0.6 \pm 0.08\end{array}$ \\
\hline MATR3 & $\begin{array}{l}\text { Increase } \\
\text { Decrease } \\
\text { No change }\end{array}$ & $\begin{array}{l}2 \\
5 \\
1\end{array}$ & $\begin{array}{l}1041 \pm 188 \\
8357 \pm 2090 \\
881\end{array}$ & $\begin{array}{l}4358 \pm 1108 \\
3673 \pm 1848 \\
882\end{array}$ & $\begin{array}{l}4.5 \pm 1.90 \\
0.5 \pm 0.10\end{array}$ \\
\hline MORC3 & $\begin{array}{l}\text { Increase } \\
\text { Decrease } \\
\text { No change }\end{array}$ & $\begin{array}{l}4 \\
2 \\
2\end{array}$ & $\begin{array}{c}166 \pm 22 \\
1502 \pm 458 \\
2235 \pm 1319\end{array}$ & $\begin{array}{c}1733 \pm 1354 \\
835 \pm 330 \\
2485 \pm 1513\end{array}$ & $\begin{array}{l}2.1 \pm 0.80 \\
0.5 \pm 0.05\end{array}$ \\
\hline PCMTD2 & $\begin{array}{l}\text { Increase } \\
\text { Decrease } \\
\text { No change }\end{array}$ & $\begin{array}{l}5 \\
1 \\
2\end{array}$ & $\begin{array}{l}656 \pm 226 \\
891 \\
819 \pm 519\end{array}$ & $\begin{array}{l}2276 \pm 1006 \\
700 \\
884 \pm 594\end{array}$ & $\begin{array}{l}2.7 \pm 0.98 \\
0.8\end{array}$ \\
\hline PDCD10 & $\begin{array}{l}\text { Increase } \\
\text { Decrease } \\
\text { No change }\end{array}$ & $\begin{array}{l}6 \\
2 \\
0\end{array}$ & $\begin{array}{c}924 \pm 313 \\
7067 \pm 2439\end{array}$ & $\begin{array}{r}10828 \pm 6560 \\
4756 \pm 3138\end{array}$ & $\begin{array}{l}3.9 \pm 0.71 \\
0.6 \pm 0.25\end{array}$ \\
\hline PSMB1 & $\begin{array}{l}\text { Increase } \\
\text { Decrease } \\
\text { No change }\end{array}$ & $\begin{array}{l}6 \\
0 \\
2\end{array}$ & $\begin{array}{c}788 \pm 378 \\
3898 \pm 2078\end{array}$ & $\begin{array}{l}3137 \pm 1178 \\
4172 \pm 2566\end{array}$ & $3.3 \pm 0.64$ \\
\hline RMND5A & $\begin{array}{l}\text { Increase } \\
\text { Decrease } \\
\text { No change }\end{array}$ & $\begin{array}{l}5 \\
2 \\
1\end{array}$ & $\begin{array}{l}816 \pm 294 \\
6091 \pm 1403 \\
1756\end{array}$ & $\begin{array}{l}13569 \pm 8201 \\
3172 \pm 560 \\
1495\end{array}$ & $\begin{array}{r}7 \pm 3.07 \\
0.5 \pm 0.05\end{array}$ \\
\hline RUNX2 & $\begin{array}{l}\text { Increase } \\
\text { Decrease } \\
\text { No change }\end{array}$ & $\begin{array}{l}4 \\
2 \\
2\end{array}$ & $\begin{array}{r}399 \pm 187 \\
3277 \pm 108 \\
584 \pm 479\end{array}$ & $\begin{array}{r}1081 \pm 447 \\
1236 \pm 413 \\
498 \pm 408\end{array}$ & $\begin{array}{l}2.1 \pm 0.24 \\
0.4 \pm 0.10\end{array}$ \\
\hline SACM1L & $\begin{array}{l}\text { Increase } \\
\text { Decrease } \\
\text { No change }\end{array}$ & $\begin{array}{l}5 \\
3 \\
0\end{array}$ & $\begin{array}{c}352 \pm 157 \\
6006 \pm 2751\end{array}$ & $\begin{array}{r}742 \pm 284 \\
1524 \pm 481\end{array}$ & $\begin{array}{l}1.7 \pm 0.19 \\
0.4 \pm 0.11\end{array}$ \\
\hline TMEM66 & $\begin{array}{l}\text { Increase } \\
\text { Decrease } \\
\text { No change }\end{array}$ & $\begin{array}{l}3 \\
3 \\
2\end{array}$ & $\begin{array}{r}2900 \pm 1496 \\
26174 \pm 7780 \\
3626 \pm 1691\end{array}$ & $\begin{array}{r}16501 \pm 5145 \\
12398 \pm 4596 \\
3905 \pm 1900\end{array}$ & $\begin{array}{r}3 \pm 0.25 \\
0.5 \pm 0.17\end{array}$ \\
\hline ZNF644 & $\begin{array}{l}\text { Increase } \\
\text { Decrease } \\
\text { No change }\end{array}$ & $\begin{array}{l}4 \\
4 \\
0\end{array}$ & $\begin{array}{c}221 \pm 106 \\
2026 \pm 1062\end{array}$ & $\begin{array}{l}1040 \pm 377 \\
1012 \pm 467\end{array}$ & $\begin{array}{l}2.9 \pm 0.29 \\
0.6 \pm 0.08\end{array}$ \\
\hline
\end{tabular}

B, Relative gene expression prior to and following chemotherapy with Adriamycin and cyclophosphamide

\begin{tabular}{lllcrr}
\hline Gene & Expression & N & Pre-CT & Post-CT & Ratio \\
\hline ATM & Increase & 4 & $1589 \pm 453$ & $2385 \pm 697$ & $1.5 \pm 0.11$ \\
& Decrease & 4 & $2655 \pm 460$ & $235 \pm 139$ & $0.5 \pm 0.08$ \\
& No change & 2 & $2554 \pm 951$ & $16094 \pm 4490$ & $2 \pm 0.39$ \\
eIF4B & Increase & 4 & $7622 \pm 1114$ & 8304 & $0.6 \pm 0.09$ \\
& Decrease & 5 & $11250 \pm 1730$ & $4154 \pm 1027$ & $1.5 \pm 0.07$ \\
No change & 1 & 9430 & $2154 \pm 347$ & 1276
\end{tabular}


Table IV. Continued.

\begin{tabular}{|c|c|c|c|c|c|}
\hline Gene & Expression & $\mathrm{N}$ & Pre-CT & Post-CT & Ratio \\
\hline MORC3 & $\begin{array}{l}\text { Increase } \\
\text { Decrease } \\
\text { No change }\end{array}$ & $\begin{array}{l}3 \\
5 \\
2\end{array}$ & $\begin{array}{l}842 \pm 72 \\
1135 \pm 70 \\
1090 \pm 106\end{array}$ & $\begin{array}{c}1302 \pm 127 \\
786 \pm 112 \\
1066 \pm 59\end{array}$ & $\begin{array}{l}1.6 \pm 0.12 \\
0.7 \pm 0.06\end{array}$ \\
\hline PCMTD2 & $\begin{array}{l}\text { Increase } \\
\text { Decrease } \\
\text { No change }\end{array}$ & $\begin{array}{l}3 \\
3 \\
4\end{array}$ & $\begin{array}{l}791 \pm 71 \\
864 \pm 380 \\
993 \pm 256\end{array}$ & $\begin{array}{r}1247 \pm 318 \\
405 \pm 173 \\
976 \pm 250\end{array}$ & $\begin{array}{l}1.5 \pm 0.27 \\
0.5 \pm 0.09\end{array}$ \\
\hline PDCD10 & $\begin{array}{l}\text { Increase } \\
\text { Decrease } \\
\text { No change }\end{array}$ & $\begin{array}{l}7 \\
2 \\
1\end{array}$ & $\begin{array}{l}4348 \pm 1448 \\
2908 \pm 111 \\
2628\end{array}$ & $\begin{array}{l}10148 \pm 7747 \\
1873 \pm 64 \\
2967\end{array}$ & $\begin{array}{r}2 \pm 0.46 \\
0.6 \pm 0.00\end{array}$ \\
\hline PSMB1 & $\begin{array}{l}\text { Increase } \\
\text { Decrease } \\
\text { No change }\end{array}$ & $\begin{array}{l}6 \\
4 \\
0\end{array}$ & $\begin{array}{l}5489 \pm 3056 \\
2966 \pm 481\end{array}$ & $\begin{array}{c}15822 \pm 12499 \\
1877 \pm 362\end{array}$ & $\begin{array}{l}1.7 \pm 0.41 \\
0.6 \pm 0.09\end{array}$ \\
\hline RMND5A & $\begin{array}{l}\text { Increase } \\
\text { Decrease } \\
\text { No change }\end{array}$ & $\begin{array}{l}4 \\
4 \\
2\end{array}$ & $\begin{array}{c}920 \pm 150 \\
3032 \pm 1351 \\
807 \pm 131\end{array}$ & $\begin{array}{c}1741 \pm 288 \\
1518 \pm 446 \\
852 \pm 98\end{array}$ & $\begin{array}{l}1.9 \pm 0.14 \\
0.6 \pm 0.12\end{array}$ \\
\hline RUNX2 & $\begin{array}{l}\text { Increase } \\
\text { Decrease } \\
\text { No change }\end{array}$ & $\begin{array}{l}4 \\
4 \\
2\end{array}$ & $\begin{array}{c}632 \pm 96 \\
1441 \pm 306 \\
444 \pm 180\end{array}$ & $\begin{array}{r}1241 \pm 187 \\
755 \pm 177 \\
437 \pm 155\end{array}$ & $\begin{array}{l}2.1 \pm 0.33 \\
0.5 \pm 0.05\end{array}$ \\
\hline SACM1L & $\begin{array}{l}\text { Increase } \\
\text { Decrease } \\
\text { No change }\end{array}$ & $\begin{array}{l}3 \\
6 \\
1\end{array}$ & $\begin{array}{l}953 \pm 99 \\
1124 \pm 251 \\
584\end{array}$ & $\begin{array}{l}1497 \pm 127 \\
631 \pm 141 \\
584\end{array}$ & $\begin{array}{l}1.6 \pm 0.25 \\
0.6 \pm 0.09\end{array}$ \\
\hline TMEM66 & $\begin{array}{l}\text { Increase } \\
\text { Decrease } \\
\text { No change }\end{array}$ & $\begin{array}{l}2 \\
6 \\
2\end{array}$ & $\begin{array}{r}6941 \pm 2765 \\
11805 \pm 1983 \\
7143 \pm 2734\end{array}$ & $\begin{array}{l}9935 \pm 3096 \\
6396 \pm 775 \\
7808 \pm 3201\end{array}$ & $\begin{array}{l}1.5 \pm 0.15 \\
0.6 \pm 0.04\end{array}$ \\
\hline ZNF644 & $\begin{array}{l}\text { Increase } \\
\text { Decrease } \\
\text { No change }\end{array}$ & $\begin{array}{l}2 \\
6 \\
2\end{array}$ & $\begin{array}{c}1072 \pm 239 \\
1016 \pm 244 \\
773 \pm 99\end{array}$ & $\begin{array}{c}2148 \pm 1179 \\
484 \pm 62 \\
802 \pm 80\end{array}$ & $\begin{array}{l}1.9 \pm 0.65 \\
0.5 \pm 0.07\end{array}$ \\
\hline
\end{tabular}

Every measure was the result of triplicate samples. $\mathrm{N}$ indicates the number of cases in which the expression of each gene was increased, decreased or not significantly altered following CT. Ratio shows the mean and typical error of the increased or decreased quotient between relative gene expression prior to and following CT (Pre-/Post-CT) for each patient. CT, chemotherapy; Pre-CT, prior to CT; Post-CT, following CT; PC, paclitaxel and carboplatin; AC, Adriamycin and cyclophosphamide; ATM, ataxia-telangiectasia mutated gene; eIF4B, translation initiation factor 4B; MATR3, Matrin 3; MORC3, microrchidia 3; PCMTD2, protein-L-isoaspartate O-methyltransferase; PDCD10, programmed cell death gene 10; PSMB1, proteasome subunit type $\beta$; RMND5A, required for meiotic nuclear division 5 homologue A; RUNX2, runt-related transcription factor 2; SACM1L, suppressor of actin mutations 1-like; TMEM66, transmembrane protein 66; ZNF644, zinc finger protein 644.

of mRNA by PCR (11) and the generation and screening of cDNA subtraction libraries (12). We selected the last method in order to obtain cDNA clones that could be used to analyse or produce recombinant proteins and subsequent antibodies for lesser known genes and proteins. This study specifically concerns the construction and screening of the library, the description of differential genes and their analysis in two groups of patients undergoing CT. Thus, in addition to patients receiving $\mathrm{PC}$, we extended our study to women suffering from breast cancer who were undergoing doxorubicin (Adriamycin) and cyclophosphamide treatment in the adjuvant setting in order to differentiate genes whose expression varies as a general response to CT from those which are more specifically correlated with PC treatment.

The ATM gene is distinctive as mutations in this gene are associated with the ataxia telangiectasia disorder. ATM is a central transducer of DNA damage signals and ensures the normal repair of DNA ds breaks (13). ATM belongs to the PI3/PI4-kinase family and is a cell cycle checkpoint kinase that functions as a regulator of a wide variety of downstream proteins, including the tumour suppressor proteins p53, BRCA1, CHK2, RAD17 and RAD9 and the DNA repair protein NBS1. The ATM and ATR proteins are closely related and control the cell cycle checkpoint signalling pathways that are required for cellular responses to DNA damage and for genome stability (14). We suggest that leukocytes upregulate the ATM gene during CT in order to repair DNA that has been damaged by drugs.

eIF4B stimulates the helicase activity of the DEAD box protein translation initiation factor $4 \mathrm{~A}$ (eIF4A) to unwind the inhibitory secondary structure of the 5 ' untranslated region of eukaryotic mRNAs. Increasing the expression of the eIF4B gene might be a general response to $\mathrm{CT}$ in order to accelerate the synthesis of proteins involved in drug resistance or 


\begin{tabular}{|c|c|c|c|c|c|c|c|c|c|c|c|c|}
\hline & & ATM & & & & & & & & & & \\
\hline \multirow{2}{*}{ EIF4B } & $\mathrm{PC}$ & $\mathrm{ns}$ & & & & & & & & & & \\
\hline & $\mathrm{AC}$ & ns & EIF4B & & & & & & & & & \\
\hline \multirow[b]{2}{*}{ MATR3 } & $\mathrm{PC}$ & $\mathrm{ns}$ & + & & & & & & & & & \\
\hline & $A C$ & + & $\mathrm{ns}$ & MATR3 & & & & & & & & \\
\hline \multirow[b]{2}{*}{ MORC3 } & $\mathrm{PC}$ & + & ns & ns & & & & & & & & \\
\hline & $A C$ & $\mathrm{~ns}$ & $\mathrm{~ns}$ & $\mathrm{~ns}$ & MORC3 & & & & & & & \\
\hline \multirow[b]{2}{*}{ PCMTD2 } & $\mathrm{PC}$ & $\mathrm{ns}$ & $\mathrm{ns}$ & $\mathrm{ns}$ & + & & & & & & & \\
\hline & $\mathrm{AC}$ & + & $\mathrm{ns}$ & $\mathrm{ns}$ & $\mathrm{ns}$ & PCMTD2 & & & & & & \\
\hline \multirow[b]{2}{*}{ PDCD10 } & $\mathrm{PC}$ & $\mathrm{ns}$ & $\mathrm{ns}$ & $\mathrm{ns}$ & + & + & & & & & & \\
\hline & $\mathrm{AC}$ & ns & $\mathrm{ns}$ & $\mathrm{ns}$ & $\mathrm{ns}$ & - & PDCD10 & & & & & \\
\hline \multirow[b]{2}{*}{ PSMBI } & $P C$ & + & $\mathrm{ns}$ & ns & + & $\mathrm{ns}$ & + & & & & & \\
\hline & $A C$ & - & $\mathrm{ns}$ & $\mathrm{ns}$ & $\mathrm{ns}$ & - & + & PSMB1 & & & & \\
\hline \multirow[b]{2}{*}{ RMNS5A } & $\mathrm{PC}$ & $\mathrm{ns}$ & $\mathrm{ns}$ & $\mathrm{ns}$ & + & + & + & ns & & & & \\
\hline & $A C$ & ns & $\mathrm{ns}$ & + & ns & $\mathrm{ns}$ & $\mathrm{ns}$ & ns & RMNS5A & & & \\
\hline \multirow[b]{2}{*}{ RUNX2 } & $\mathrm{PC}$ & + & $\mathrm{ns}$ & $\mathrm{ns}$ & + & $\mathrm{ns}$ & + & + & + & & & \\
\hline & $A C$ & $\mathrm{~ns}$ & $\mathrm{~ns}$ & $\mathrm{~ns}$ & ns & $\mathrm{ns}$ & $\mathrm{ns}$ & $\mathrm{ns}$ & + & RUNX & & \\
\hline \multirow[b]{2}{*}{ SACMIL } & $\mathrm{PC}$ & + & ns & ns & + & ns & ns & + & + & + & & \\
\hline & $A C$ & + & $\mathrm{ns}$ & + & $\mathrm{ns}$ & $\mathrm{ns}$ & $\mathrm{ns}$ & ns & $\mathrm{ns}$ & ns & SACMIL & \\
\hline \multirow[b]{2}{*}{ TMEM 66} & $\mathrm{PC}$ & + & $\mathrm{ns}$ & $\mathrm{ns}$ & + & $\mathrm{ns}$ & + & + & + & + & + & \\
\hline & $A C$ & $\mathrm{~ns}$ & + & ns & $\mathrm{ns}$ & $\mathrm{ns}$ & $\mathrm{ns}$ & $\mathrm{ns}$ & + & + & ns & TMEM66 \\
\hline \multirow[b]{2}{*}{ ZNF644 } & $P C$ & + & $\mathrm{ns}$ & ns & + & ns & + & + & + & + & + & + \\
\hline & $\mathrm{AC}$ & $\mathrm{ns}$ & + & ns & ns & $\mathrm{ns}$ & + & + & ns & ns & ns & + \\
\hline
\end{tabular}

Figure 1. Correlations between the studied genes. +, positive correlation, $\mathrm{P}<0.01$; -, negative correlation, $\mathrm{P}<0.01$; ns, no significant correlation; $\mathrm{PC}$, paclitaxel and carboplatin; AC, Adriamycin and cyclophosphamide; ATM, ataxia-telangiectasia mutated gene; eIF4B, translation initiation factor 4B; MATR3, Matrin 3; MORC3, microrchidia 3; PCMTD2, protein-L-isoaspartate O-methyltransferase; PDCD10, programmed cell death gene 10; PSMB1, proteasome subunit type $\beta$; RMND5A, required for meiotic nuclear division 5 homologue A; RUNX2, runt-related transcription factor 2; SACM1L, suppressor of actin mutations 1-like; TMEM66, transmembrane protein 66; ZNF644, zinc finger protein 644.

metabolic changes involved in cell survival, but the helicase activity of eIF4B suggests that its upregulation is more specifically correlated with carboplatin treatment (15).

MATR3 is a nuclear matrix protein that has been reported to interact with other nuclear proteins to anchor RNAs to the nuclear matrix, modulate the activity of proximal promoters and to be the main PKA substrate following the activation of the NMDA receptor (16). Two transcript variants encoding the same protein have been identified for this gene. Matrin 3 has been identified as a $\mathrm{Ca}^{2+}$-dependent $\mathrm{CaM}$-binding protein and a downstream substrate for caspases (17). MATR3 acts as a co-factor of the HIV-1 Rev protein during nuclear export and the translation of unspliced and partially spliced viral mRNA (18).

MORC3, also termed KIAA0136, ZCWCC3 and NXP-2, encodes a member of the MORC protein family, which is characterised by conserved structures consisting of a GHL (Gyrase B, Hsp90 and MutL)-ATPase domain, a zinc finger-type $\mathrm{CW}$ domain (four cysteines and two tryptophans), a nuclear localisation signal (NLS) and coiled-coil domains at the carboxy-terminus, as mentioned in (19). MORC 3 is ubiquitously expressed in humans, localises to the nuclear matrix, has RNA binding activity and regulates p53 activity and localisation to promyelocytic leukaemia-nuclear bodies (PML-NBs) (19). The upregulation of MATR3 and MORC3 may indicate an attempt to drive an injured cell, through the caspase and $\mathrm{p} 53$ pathways, to apoptosis.

PCMTD2 is also termed PIMT (protein-L-isoaspartate O-methyltransferase). The formation of L-isoaspartyl (isoAsp) peptide bonds is a major source of protein damage in vivo and in vitro. PIMT is a protein repair enzyme that converts
L-isoaspartyl residues in damaged proteins to normal L-aspartyl residues. In rat nucleosomes, the histone $\mathrm{H} 2 \mathrm{~B}$ was found to accumulate isoAsp in the Asp25-Gly26 bond in the N-terminal tail. In chicken nucleosomes, isoAsp accumulated mainly in histone $\mathrm{H} 2 \mathrm{~A}$ and, to a lesser extent, in histone H2B (20-22).

PDCD10 is also known as cerebral cavernous malformation-3 and CCM3. This gene encodes an evolutionarily conserved protein which is associated with cell apoptosis and has multiple alternatively spliced variants encoding the same protein (23). The protein interacts with the serine/threonine protein kinase MST4 to modulate the extracellular signal-regulated kinase (ERK) pathway. The protein also interacts with and is phosphorylated by serine/threonine kinase 2 in a signalling pathway, which is critical for vascular development (24). Gene chip data have suggested that PDCD10 is involved in tumour signalling, as it was shown to be upregulated in pancreatic adenocarcinoma (25), metastatic colon cancer cells resistant to cisplatin-induced apoptosis and other cancer cell lines (26). Thus, our data suggest that the interaction pathway PDCD10MST4-ERK-MAPK, one of the most significant regulators of cell proliferation, is also affected by the two CT therapies investigated in the present study.

The PSMB1 proteasome is a multicatalytic proteinase complex with a highly ordered ring-shaped core structure. This gene encodes a member of the proteasome B-type family, also known as the T1B family, with a 20S core $\beta$ subunit. The PSMB1 subunit is critical for the degradation of several proteins, more specifically those involved in cell proliferation and cancer (27).

RMND5A, also known as CTLH, RMD5, p44CTLH, FLJ12753, FLJ13910, FLJ21795 and MGC78451, forms 
complexes in cells with RanBPM, ARMC8 $\alpha$, ARMC8 $\beta$, Muskelin and p48EMLP. RMND5A is a key component of the CTLH complex (C-terminal to lissencephaly type-1-like homology motif). This complex is involved in microtubule dynamics, cell migration, nucleokinesis and chromosome segregation (28). Therefore, the variations in the expression of the RMND5A gene may be due to the effects of paclitaxel.

RUNX2 is a member of the RUNX family of transcription factors, which are essential for osteoblast growth and differentiation and chondrocyte maturation. RUNX2 encodes a nuclear protein with a Runt DNA-binding domain that controls the expression of target genes involved in cell fate decisions (29). Runx-2 isoforms are produced by transcript variants caused by alternative promoters and alternative splicing. In the osteosarcoma cell line Saos2, Runx2 has been shown to regulate apoptosis via modulation of the Bcl2 family of proteins (30).

The SACM1L gene encodes a phosphoinositide phosphatase that is an integral membrane protein of the endoplasmic reticulum (ER) and the Golgi apparatus representing a class of phosphoinositide degradation enzymes $(31,32)$. The integral membrane Sacl phosphatases are a major class of this type of enzyme. Additionally, SAC1 accumulates in the Golgi complex of quiescent cells and suppresses anterograde trafficking by depleting Golgi PI(4)P (33).

For the purposes of our study, the reported case of a mixed lineage leukaemia MLL-rearrangement with the suppressor of actin mutations 1-like (MLL-SACM1L) rearrangement is significant. This rearrangement was observed in bone marrow cells during CT for acute lymphoblastic leukaemia with hyperdiploidy and was continuously detected over seven years without exhibiting clonal expansion (34).

TMEM66, also known as XTP3, FOAP-7, HSPC035, MGC8721 and FLJ22274, is regarded as a potential marker for prostate cancer, included into a group of secreted proteins $(35,36)$ and counted among others in a screening for proapoptotic genes (37). No specific function has yet been attributed to the protein product of this gene.

ZNF644 (38) is a large multizinc finger homologue of the KIAA1221 and WIZ proteins (39). It has been reported that these three proteins co-purified with CDYL, which is associated with histone methylase G9a and mediates a REST tumour suppression function. The specific function of ZNF644 is currently unknown.

All the studied genes in the patients from the PC group showed a positive correlation with each other, with the marked exception of eIF4B and MATR3. Most of these correlations were not found in the $\mathrm{AC}$ patient group; furthermore, some of the correlations were negative in this group. Notably, MORC3 and ZNF644 in the PC patients had a positive correlation with the rest of the genes, whereas, in the AC patients, MORC3 did not show a correlation with any gene and ZNF644 was correlated with only a few genes.

A high correlation of the levels of expression of most of the identified genes coding for cytosolic and nuclear proteins were included in the cellular multidynamic system and signal transduction groups (Table II). The balance in the variation in their expression drives the cell to life versus apoptosis as a response to cellular damage induced by CT. This expression pattern corresponds to the pattern for CT-surviving cells, assuming that cells that did not react by modifying the expression of these genes, thereby inducing apoptosis and cell death. This hypothesis is further supported by the different expression patterns observed in the leukocytes obtained from AC-treated patients. The few up- or downregulations the PCand AC-treated groups have in common are likely to be due to the similar modes of action of carboplatin and Adriamycin and the manner in which cells react to the two drugs.

A notable differential positive correlation between the PC and $\mathrm{AC}$ groups is that of PCMTD2 with PDCD10 and the nonsignificant PCMTD2 with PSMB1 in PC-treated patients. In the case of AC-treated patients, the expression of the PCMTD2 gene showed a negative correlation with the expression of PDCD10 and PSMB1. As such, the expression of an apoptosis regulatory gene was correlated with a protein repair gene and not a proteasome subunit gene in the PC-treated group. However, the same apoptosis regulatory gene in AC-treated patients was negatively correlated with the protein repair gene and the proteasome subunit gene. This further supports the theory that the increased expression of genes that are involved in protein repair and damaged protein degradation following PC treatment is indicative of an attempt to rescue the cells from the effects of PC-induced cytotoxicity.

In the PC-treated patients, the amount of circulating platelets and the expression levels of the ATM, MORC, PSMB1, RUNX TMEM and ZNF genes showed a negative correlation $(\mathrm{P}<0.05)$. No other correlation between groups of patients with up- or downregulated genes and clinical parameters, including anaemia, fever, secondary neuropathy or mucositis, has been demonstrated for any of the studied parameters.

The results indicate a heterogeneous response of white cells (Tables IVA and B) resulting in different populations that have the up- or downregulation of the expression of certain genes in common. The contradictory responses of cells which contemporaneously increased the expression of genes involved in the survival and apoptotic responses may be due to the critical moment at which cells are committed to evolving and surviving or being eliminated by apoptosis.

This study was performed with a reduced sample of patients, as a pilot study, to identify genes whose expression levels are affected by CT. Now that the changes in gene expression are known, further studies should be performed with a larger cohort of patients and a longer follow-up period to ascertain whether certain genes are associated with specific clinical or analytical manifestations.

The patients treated with PC CT had stage III-IV non-small cell lung cancer or gynaecological cancer. This group of patients have a high incidence of chronic anaemia, reducing the possibility of identifying the effects of the changes in gene expression on the development of bone marrow toxicity.

Certain genes that showed altered patterns of expression in the leukocytes may be involved in the generation of the nondesirable effects of CT in normal blood cells. In the short-term, it should be determined whether there is any association between these changes and immune deficiency, which leads to infectious complications in a reversible or permanent manner. This is critical in establishing prognostic significance in terms of immune surveillance and the recurrence rate.

If these variations in gene expression originate in stem cells, they may be important for CT-associated anaemia or, in the long-term, for myelodysplastic syndromes. If these 
CT-induced alterations in gene expression also occur in tumour cells, we should expect them to contribute, in heavily treated patients, to an increased genomic instability and rapid disease progression. More studies are necessary to determine whether these changes in gene expression are correlated with the shortand/or long-term toxicities of anticancer CT. Additionally, whether these changes are random or directed in a specific selection-evolution manner also needs to be elucidated.

\section{Acknowledgements}

This study was supported by grants from the Grupo Hospiten, Tenerife, Spain to M.M.; FIS PS09/0128 to J.A. and FIS PI11/00141, Spain, to P. M-V. The authors thank Dr Eduardo Salido, Facultad de Medicina, Universidad de La Laguna, Spain and Dr Ali Mobasheri, Nottingham University Vet School, UK, for their critical reading and editorial help.

\section{References}

1. DeVita V (author), DePinho RA (ed), Lawrence TS (ed), Rosenberg SA (ed) and Weinberg RA (ed): DeVita, Hellman, and Rosenberg's Cancer: Principles and Practice of Oncology. 9th edition, Lippincott Williams \& Wilkins, Philadelphia, 2011.

2. Perry MC (ed): The Chemotherapy Source Book. 4th edition. Lippincott Williams \& Wilkins, Philadelphia, 2008.

3. Kavallaris M, Kuo DY, Burkhart CA, et al: Taxol-resistant epithelial ovarian tumors are associated with altered expression of specific beta-tubulin isotypes. J Clin Invest 100: 1282-1293, 1997.

4. Steffensen KD, Waldstrom M and Jakobsen A: The relationship of platinum resistance and ERCC1 protein expression in epithelial ovarian cancer. Int J Gynecol Cancer 19: 820-825, 2009.

5. Smith L, Watson MB, O'Kane SL, Drew PJ, Lind MJ and Cawkwell L: The analysis of doxorubicin resistance in human breast cancer cells using antibody microarrays. Mol Cancer Ther 5: 2115-2120, 2006.

6. Watts GS, Futscher BW, Isett R, Gleason-Guzman M, Kunkel MW and Salmon SE: cDNA microarray analysis of multidrug resistance: doxorubicin selection produces multiple defects in apoptosis signaling pathways. J Pharmacol Exp Ther 299: 434-441, 2001.

7. Ekhart C, Doodeman VD, Rodenhuis S, Smits PH, Beijnen JH and Huitema AD: Influence of polymorphisms of drug metabolizing enzymes (CYP2B6, CYP2C9, CYP2C19, CYP3A4, CYP3A5, GSTA1, GSTP1, ALDH1A1 and ALDH3A1) on the pharmacokinetics of cyclophosphamide and 4-hydroxycyclophosphamide. Pharmacogenet Genomics 18: 515-523, 2008.

8. Sambrook J, Fritsch EF and Maniatis T: Molecular Cloning: A Laboratory Manual. 2nd edition. Cold Spring Harbor Laboratory, 1989.

9. Altschul SF, Madden TL, Schaffer AA, et al: Gapped BLAST and PSI-BLAST: a new generation of protein database search programs. Nucleic Acids Res 25: 3389-3402, 1997.

10. Velculescu VE, Zhang L, Vogelstein B and Kinzler KW: Serial analysis of gene expression. Science 270: 484-487, 1995.

11. Liang P and Pardee AB: Differential display of mRNA by PCR. Curr Protoc Mol Biol, Chapter 25: Unit 25B.3. 2001

12. Diatchenko L, Lau YF, Campbell AP, et al: Suppression subtractive hybridization: a method for generating differentially regulated or tissue-specific cDNA probes and libraries. Proc Natl Acad Sci USA 93: 6025-6030, 1996.

13. Bensimon A, Aebersold R and Shiloh Y: Beyond ATM: the protein kinase landscape of the DNA damage response. FEBS Lett 585: 1625-1639, 2011.

14. Lavin MF: Ataxia-telangiectasia: from a rare disorder to a paradigm for cell signalling and cancer. Nat Rev Mol Cell Biol 9: 759-769, 2008

15. Parsyan A, Svitkin Y, Shahbazian D, et al: mRNA helicases: the tacticians of translational control. Nat Rev Mol Cell Biol 12: 235-245, 2011.

16. Przygodzka P, Boncela J and Cierniewski CS: Matrin 3 as a key regulator of endothelial cell survival. Exp Cell Res 317: 802-811, 2011.
17. Valencia CA, Ju W and Liu R: Matrin 3 is a $\mathrm{Ca}^{2+} /$ calmodulinbinding protein cleaved by caspases. Biochem Biophys Res Commun 361: 281-286, 2007

18. Kula A, Guerra J, Knezevich A, Kleva D, Myers MP and Marcello A: Characterization of the HIV-1 RNA associated proteome identifies Matrin 3 as a nuclear cofactor of Rev function. Retrovirology 8: 60, 2011

19. Takahashi K, Yoshida N, Murakami N, et al: Dynamic regulation of p53 subnuclear localization and senescence by MORC3. Mol Biol Cell 18: 1701-1709, 2007.

20. Shimizu T, Matsuoka Y and Shirasawa T: Biological significance of isoaspartate and its repair system. Biol Pharm Bull 28: 1590-1596, 2005

21. Young GW, Hoofring SA, Mamula MJ, et al: Protein L-isoaspartyl methyltransferase catalyzes in vivo racemization of Aspartate-25 in mammalian histone H2B. J Biol Chem 280: 26094-26098, 2005.

22. Carter WG and Aswad DW: Formation, localization, and repair of L-isoaspartyl sites in histones $\mathrm{H} 2 \mathrm{~A}$ and $\mathrm{H} 2 \mathrm{~B}$ in nucleosomes from rat liver and chicken erythrocytes. Biochemistry 47: 10757-10764, 2008.

23. Lauenborg B, Kopp K, Krejsgaard T, et al: Programmed cell death-10 enhances proliferation and protects malignant $\mathrm{T}$ cells from apoptosis. APMIS 118: 719-728, 2010.

24. Ma X, Zhao H, Shan J, et al: PDCD10 interacts with Ste20related kinase MST4 to promote cell growth and transformation via modulation of the ERK pathway. Mol Biol Cell 18: 19651978, 2007

25. Aguirre AJ, Brennan C, Bailey G, et al: High-resolution characterization of the pancreatic adenocarcinoma genome. Proc Natl Acad Sci USA 101: 9067-9072, 2004

26. Huerta S, Harris DM, Jazirehi A, et al: Gene expression profile of metastatic colon cancer cells resistant to cisplatin-induced apoptosis. Int J Oncol 22: 663-670, 2003.

27. Keutgens A, Zhang X, Shostak K, et al: BCL-3 degradation involves its polyubiquitination through a FBW7-independent pathway and its binding to the proteasome subunit PSMB1. J Biol Chem 285: 25831-25840, 2010.

28. Kobayashi N, Yang J, Ueda A, et al: RanBPM, Muskelin, p48EMLP, p44CTLH, and the armadillo-repeat proteins ARMC8alpha and ARMC8beta are components of the CTLH complex. Gene 396: 236-247, 2007.

29. Pratap J, Lian JB, Javed A, et al: Regulatory roles of Runx2 in metastatic tumor and cancer cell interactions with bone. Cancer Metastasis Rev 25: 589-600, 2006.

30. Eliseev RA, Dong YF, Sampson E, et al: Runx2-mediated activation of the Bax gene increases osteosarcoma cell sensitivity to apoptosis. Oncogene 27: 3605-3614, 2008.

31. Rohde HM, Cheong FY, Konrad G, Paiha K, Mayinger P and Boehmelt G. The human phosphatidylinositol phosphatase SAC1 interacts with the coatomer I complex. J Biol Chem 278: 52689-52699, 2003.

32. Liu Y, Boukhelifa M, Tribble E, et al: The Sac1 phosphoinositide phosphatase regulates Golgi membrane morphology and mitotic spindle organization in mammals. Mol Biol Cell 19: 3080-3096, 2008.

33. Blagoveshchenskaya A, Cheong FY, Rohde HM, et al: Integration of Golgi trafficking and growth factor signaling by the lipid phosphatase SAC1. J Cell Biol 180: 803-812, 2008.

34. Mori T, Nishimura N, Hasegawa D, et al: Persistent detection of a novel MLL-SACM1L rearrangement in the absence of leukemia. Leuk Res 34: 1398-1401, 2010.

35. Romanuik TL, Ueda T, Le N, et al: Novel biomarkers for prostate cancer including noncoding transcripts. Am J Pathol 175: 2264-2276, 2009.

36. Romanuik TL, Wang G, Holt RA, Jones SJ, Marra MA and Sadar MD: Identification of novel androgen-responsive genes by sequencing of LongSAGE libraries. BMC Genomics 10: 476, 2009.

37. Mannherz O, Mertens D, Hahn M and Lichter P: Functional screening for proapoptotic genes by reverse transfection cell array technology. Genomics 87: 665-672, 2006.

38. Mulligan P, Westbrook TF, Ottinger M, et al: CDYL bridges REST and histone methyltransferases for gene repression and suppression of cellular transformation. Mol Cell 32: 718-726, 2008.

39. Matsumoto K, Ishii N, Yoshida S, Shiosaka S, Wanaka A and Tohyama M: Molecular cloning and distinct developmental expression pattern of spliced forms of a novel zinc finger gene wiz in the mouse cerebellum. Brain Res Mol Brain Res 61: 179-189, 1998 